\title{
The Moderating Effect of Transformational Leadership on the Relationship between Organizational Culture and Organizational Effectiveness: An Empirical Study in Food Companies Listed at the Amman Stock Exchange-Jordan
}

\author{
Ayman Faisal Habtoosh ${ }^{1} \&$ Mohi-Adden Y. Al-Qutop ${ }^{1}$ \\ ${ }^{1}$ Business Administration Department, Petra University, Amman, Jordan \\ Correspondence: Dr. Mohi-Adden Y. Al-Qutop, Business Administration Department, Petra University, Amman, \\ Jordan. E-mail: malqutop@uop.edu.jo
}

Received: February 8, 2019

doi:10.5539/ijbm.v14n4p157

\begin{abstract}
The main aim of this study is to investigate the moderating effect of Transformational Leadership (Inspirational Motivation, Intellectual Stimulation, and Idealized Influence) on the relationship between Organizational Culture (Teamwork and Innovation) and Organizational Effectiveness in Food Companies listed at the Amman Stock Exchange -Jordan.

The data was gathered through a questionnaire that was designed and distributed to convenient sample units that represented these Food Companies. A total of 236 respondents participated by answering the questionnaire, and they represented 10 percent of companies' employees.

Descriptive analytical approaches were used to analyze the data for this study using Statistical Package for Social Sciences program V.21.

The study results show that there was a significant statistical effect of Organizational Culture on Organizational Effectiveness, and there was a significant statistical moderating effect of Transformational Leadership on the relationship between Organizational Culture and Organizational Effectiveness in Food Companies listed at Amman Stock Exchange.

The study recommended that these Companies need to adopt behavioral training programs for the current managers and supervisors to promote the transformational leadership style and create a climate of mutual trust and respect with employees and inspire and motivate them intellectually to increase the positive impact of transformational leadership on the relationship between organizational culture and organizational effectiveness.
\end{abstract}

Keywords: Organizational Culture, Transformational Leadership, Organizational Effectiveness, Food Companies, Jordan.

\section{Introduction}

Organizations these days face a lot of challenges such as high competition, turbulent environment, and globalizations. These challenges and other situational variables forced organization to devote a lot of efforts in order to become more effective (Jones, 2013).

Organizational effectiveness is one of the main interests for all organizations these days who work toward the objectives of survival and growth; As a result, organizations put in a lot of efforts, change, and adaptation to be effective.

Effectiveness as a concept is so important when we seek to understand any organizational behavior (Chelladurai \& Haggerty, 1991).To understand organizational behavior, we need to understand how organizational effectiveness is related to the leadership and culture within an organization (Hsu, 2002).

Organizational culture, like the concept of transformational leadership, had become an important area to research and study in corporate business. Cultural variables have been in the minds of scholars of anthropology and sociology for many years. In 1979, Andrew Pettigrew introduced the concept of organizational culture in his 
paper "On Studying Organizational Cultures". Since then, organizational culture has attracted the interest of more scholars than anticipated, and became a subject as central as leadership in management research (Kent, 1995).

The transformational leadership model was developed by Bass (1990) is one of the most recent approaches in studying leadership; it has the advantages of earlier approaches. Furthermore, it is much stronger and more realistic than earlier approaches. This study will focus on the most recent proposed \& developed model of transformational leadership since first introduced.

\subsection{Study Significance and Importance}

The significance of this study is to investigate the impact of Organizational Culture dimensions (Teamwork and Innovation) on Organizational Effectiveness which previous studies used different cultural dimensions. In Addition, this study investigates the moderating effect of Transformational Leadership dimensions (Inspirational Motivation, Intellectual Stimulation and Idealized Influence) on the relationship between Organizational Culture and Effectiveness, which previous studies examined these variables through different relations or impacts. The theoretical importance is that many relevant studies examined the impact of Organizational Culture on Organizational Effectiveness using different dimensions for culture but this study may considered as an addition to these studies because of the use of (Teamwork and Innovation) as dimension for culture which was rarely used in studies. And the practical (Applied) importance is that based on the reports issued by Amman Industry Chamber and Amman Stock Exchange, the Food Companies listed at Amman Stock Exchange are one of the most important companies in the food industry sector in Jordan, they contribute in domestic production and national income; so the results of this study will provide feedback to these Companies and hope that it will help by giving them supportive guidance to manage Organizational Culture (Teamwork \& Innovation) to attain Organizational Effectiveness. And explain how Transformational Leadership (Inspirational Motivation, Intellectual Stimulation \& Idealized Influence) have a moderating effect on the relationship between Organizational Culture and Organizational Effectiveness within these companies.

\subsection{The Study Purpose and Objectives}

The main purpose of this study is to identify the moderating effect of Transformational Leadership (Inspirational Motivation, Intellectual Stimulations, and Idealized Influence) on the relationship between Organizational Culture (Teamwork and Innovation) and Organizational Effectiveness. Also the study aims to reach the following objectives:

(a) Provide a conceptual and theoretical framework for the study variables Organizational Culture (Teamwork and Innovation), Organizational Effectiveness, and Transformational Leadership (Inspirational Motivation, Intellectual Stimulations, and Idealized Influence).

(b)Investigate the impact of Organizational Culture (Teamwork and Innovation) on Organizational Effectiveness.

(c) Investigate the moderating effect of Transformational Leadership on the relationship between Organizational Culture and Organizational Effectiveness.

\section{Literature Review and Previous Studies}

\subsection{Organizational Culture}

After Tylors' definition of culture (1871), myriad researchers had many definitions of culture by looking at it from different angles and aspects. Kroeber \& Kluckhohn (1952, p.157) reviewed and revised these various definitions and developed an integrated definition: "Culture is a product; is historical; includes ideas, pattern, and values; is selective; is learned; is based upon symbols; and is an abstraction from behavior and the product of behavior".

Deal \& Kennedy (2000) indicated that in the term of the organizational culture, the values and beliefs would be the cultural basics that will be shared and accepted. They explained the values and beliefs as what it is all about, and what will gather us around when a situation get hard.

Jones (2013, p201) defined organizational culture as "The set of shared values and norms that control organization members' interactions with each other and with other people outside the organization". Robbins \& Judge (2013) indicates that organizational culture is a system of shared common sense, which is held by the members of an organization, which distinguishes the organization from others.

Hofstede et al, (2010:24) stated that organizations are culture bound and therefore act in a certain way. To be successful, organizations must constantly create new ideas on how to improve their operations towards innovativeness to maintain competitiveness (Kessler and Chakarbati, 1996; Tidd, 2001; Liu, 2013; Arundel et al., 
2015; Liu and Liang, 2015).

\subsubsection{Organizational Culture dimensions}

Jung et al., (2009) stated that organizational culture consists of some dimensions such as communication, teamwork, innovation, and attitudes towards change

Sanfilippo et al. (2008) expressed their expectations that in order to set a change in the organizational "values/culture" from passive-avoidant to constructive, it is essential to encourage the values of teamwork, innovation, and excellence.

Teamwork is a process that aims to facilitate interactions between team members through effective communication, coordination, and cooperation in an effort to promote successful task completion and to develop high-quality relationships among team members (Converse, et al., 1993; Salas et al., 1988).

Teamwork refers to how effective employees feel the organization is in terms of coordinating work between individuals and groups. It also involves the extent to which the efforts of individuals and groups are linked together so that each person will function effectively within the organization (Sashkin\&Sashkin, 1990; Kent, 1995; Hsu, 2002).

Teams are practical media that can foster communication between diverse people and build coalitions that result in innovation. Teams help employees and managers share hunches, doubts, and discuss emerging ideas and practices to solve and even find problems. Mutual support encourages team members to take advantage of these problems and exploit them as opportunities.

The relevance of innovations and innovative organizational culture in organizations can be described well with Chesbourghs' thoughts. He states that most of the innovations will fail, but organizations that do not innovate will die (Chesbrough, 2006:17). According to Cho et al. (2016), the characteristics of an organization and its manager explain a large portion of the variation in a firm's innovation productivity.

Because organizational culture influences employees' behavior, it may lead the personnel to accept innovation as a fundamental value of the organization and to feel more involved in it. Thus, culture can stimulate innovative behavior among the members of an organization because it can lead them to accept innovation as a basic value of the organization and foster commitment to it (Hartmann, 2006).

There was a general agreement that culture is a major force affecting employees' behavior and organizational effectiveness (Kilmann, Saxton, \& Serpa 1985) (Schein, 1990) (Marcoulides \& Heck, 1993). Numerous researchers have made empirical linkages between organizational culture and organizational effectiveness (Hammond et al., 2011).

\subsection{Leadership}

Many scholars and researchers talked about the importance of effective leadership for the organization. Bennis (2001) drew attention to the new business environment which requires a transformation in the role of leadership. A leader should be aware of the importance of the human capital whether in building knowledge, innovations, or contrivance.

Due to the changing and uncertain environment; organizations need leaders who have the ability to understand complex, rapid, and changing environment. When tasks are highly structured and leaders have excellent relationship with subordinates, the organizational effectiveness will be superior (Swamy T. S. and Swamy D. R., 2014).

One of the most studied theories in leadership is Bass's theory of transformational \& transactional leadership (Eisenbach, et al., 1999; Parry \&Thomson, 2002). These two styles are not separated from each other's (they are the two sides of the same coin).

The most known leadership style that had proved its ability over time to lead a change in organizations styles in leadership is transformational leadership. This style had helped some organizations to survive hard times (Heskett \& Kotter, 1992; Tichy \& Devanna,1986).

\subsubsection{Transformational Leadership}

The preliminary work on transformational leadership was undertaken by Burns in 1978; he identifies it as a process in which the leader raises morality and motivation of the followers to a higher level, and vice versa (Burns, 1978).

Transformational leadership has emerged as one of the most outstanding leadership styles that contributes to an organization's prosperity and sustainability (Bass \& Riggio, 2006). 
Transformational leadership had an increasing attention as a reaction to the changing social and economic factors (Saxe, 2011). Organizations shifted to focus on the processes that facilitate transformation, change, and develop organizational effectiveness, morale, and motivation for the greater advantage. All that inspired the study of transformational leadership (Hernez \& Hughes, 2004).

There is growing attention about how transformational leadership dimensions (inspirational motivation, intellectual stimulation and idealized influence) impact and develop peoples' behavior, and overrun the personal ambitions for the organization's unified purpose, mission \& vision (Blackwell S., 2006; Hater \& Bass, 1988).

\subsubsection{Transformational Leadership dimensions}

Bass (1997) indicated that transformational leadership consists of some dimensions and they are: (intellectual stimulation, idealized influence, and spiritual motivation).

Other dimensions were added or simply modified by other researches. Nowadays, transformational leadership consists of interrelated dimensions, inspirational motivation, intellectual stimulation, and idealized influence (Bass \& Riggio, 2006; Northhouse, 2010; Gilmore et al., 2013).

\subsection{Inspirational Motivation}

In this dimension, the leader motivates and inspires people by providing meaning, and challenging them. In that way he/she encompasses inspirational motivation (Bass \& Riggio, 2006). Adding to that, the leader encourages people to imagine attractive future circumstances or conditions (Bass \& Riggio, 2006)

Furthermore, these leaders clearly communicate and display a commitment to objectives, and the shared vision of an organization. Individual and team spirits are ignited through the leader's enthusiasm and optimism (Antonakis \& House, 2014).

\subsection{Intellectual Stimulation}

In this dimension, the leader stimulates peoples' efforts to be innovative and creative, by questioning assumptions, reframing problems, approaching situations in new ways, developing new \& innovative ways to resolve old problems. The leader encourages creativity, and there is no reproach if an individual makes a mistake; This is referred to as intellectual stimulation (Bass \& Avolio, 1994).

Intellectual stimulation compels people to rethink ideas that they may not have questioned before, it allows leaders to seek different perspectives when solving problems, thereby looking at the problems from varying angles. Furthermore, using intellectual stimulation, leaders can also suggest new ways of completing tasks (Bass \& Avolio, 1994).

\subsection{Idealized influence}

In this dimension, the leader is primarily associated with his ability to behave in ways that reflects strong ethics, possesses strong role-model principles, admired, respected and trusted (Gilmore et al., 2013). According to Bass and Riggio (2006), the two parts of idealized influence are the leaders' behaviors and the characteristics that people refer to the leader.

Leaders with essential amount of idealized influence are more willing to share risks with employees. Moreover, they are more likely to behave in a way that is harmonious with an organization's articulated principles and values. These leaders understand and identify the importance of having a strong sense of purpose and a collective sense of mission (Bass \& Riggio, 2006).

According to Cheng et al. (2012), transformational leaders influence people by emphasizing the meaning of the job and conveying an appealing successful future to get followers to focus on their jobs. Thus, transformational leadership is expected to have a positive influence on organizational effectiveness.

The dimensions of transformational leadership style incorporate with many of the characteristics of organizational effectiveness. Bass and Riggio (2006) reported that transformational leadership has a significantly positive effect on organizational effectiveness, job satisfaction, and work performance.

It is widely accepted that transformational leadership produces desired results in all circumstances and in different cultural settings. It is particularly suited for fast-paced, change-laden environments that demand creative problem solving, and customer commitment. (Mamo, 2017).

\subsection{Organizational Effectiveness}

Many people argue about what makes some organizations outstanding, productive, healthy, and able to produce the best quality products. This can be explained through organizational effectiveness. Many definitions were 
made by researchers depending on different viewpoints about what organizational effectiveness is.

Balduck \& Baleens (2008) pointed out that effectiveness is the accuracy in achieving goals, and that effectiveness is the best way in which an organization achieves its' goals.

Thompson (2003) mentioned that the effectiveness of an organization can be noticed by transferring inputs to outputs, and to be evaluated whether the outputs are provided with the least expenditure of the available resources.

Vinitwatanakhun (2015) conducted a study in which he explained that organizational effectiveness needs to concentrate on human resources, and to help employees to achieve skills and self-esteem to be able to control the new environment and find security and support.

Criteria of effectiveness are vast. They may include one or more of the following criteria; general effectiveness, efficiency, quality, growth, control, flexibility, duty skills of management, communication and information management, productivity, profit, participation, progress, determining goal and planning, interpersonal managerial skills, preparation, application of environmental resources, human resources, education and development (Aghayi et al., 2011).

\subsection{Organizational Culture, Transformational Leadership and Organizational Effectiveness}

The concepts of transformational leadership and organizational culture were studied extensively. There is evidence that the combination of transformational leadership and organizational culture hold great promise for advancing organizational effectiveness (Banerji \& Krishnan, 2000; Bass \& Avolio, 2005).

Transformational leadership behaviors show strong positive effects on followers' attitudes and organizational effectiveness (Bass \& Riggo, 2006). Studies examining leadership behaviors provided evidence that transformational leadership is positively correlated with employees' organizational effectiveness (Griffith, 2004; Jehangir et al., 2011; Newman, 2012; Long, et al., 2013).

Since leaders are creators and managers of organizational culture (Schein, 2010), they work and dedicate their efforts and time for the effectiveness of their organization by creating a culture that promotes organizational effectiveness (Mamo, 2017). Ogbonna and Harris (2000) have also conducted a similar kind of research study in UK and found a positive result. They found that the effect of leadership on organizational effectiveness is mediated by organizational culture.

\section{Study Methodology}

To investigate the moderating effect of Transformational Leadership on the relationship between Organizational Culture and Organizational Effectiveness in the Food Companies that are listed at the Amman Stock Exchange, the study use the descriptive analytical approach.

Based on the statement of the problem and study questions, the empirical data for this study was collected from participants who work in these Companies, and was analyzed through quantitative approach.

This study aimed to investigate the effects and relationships among study variables. To be more precise, the study investigates the moderating effect of Transformational Leadership on the relationship between Organizational Culture and Organizational Effectiveness in the Food Companies that are listed at the Amman Stock Exchange.

\subsection{Study tool and Data Collection}

In this study two data sources were used: Theoretical and practical. The theoretical part relied on previous studies, theses, dissertations, journals, and specialized books. The practical part relied on descriptive and analytical tools \& methods.

To accomplish the research objectives, the following sources were considered to collect the needed data: the Secondary Data Source: These data were collected from unpublished studies, theses, dissertations, journals, specialized books, Amman chamber of industry (ACI), Amman Stock Exchange (ASE), and World Wide Web. And Primary Data Source: Framework \& questionnaire were needed to collect data (practical part) for the study. In order to gather the primary data, a questionnaire was developed based on valid questionnaires such as (MLQ, OCAQ \& OCAI, and OES) by choosing the suitable items and modifying them to fit with the purpose of this study. 


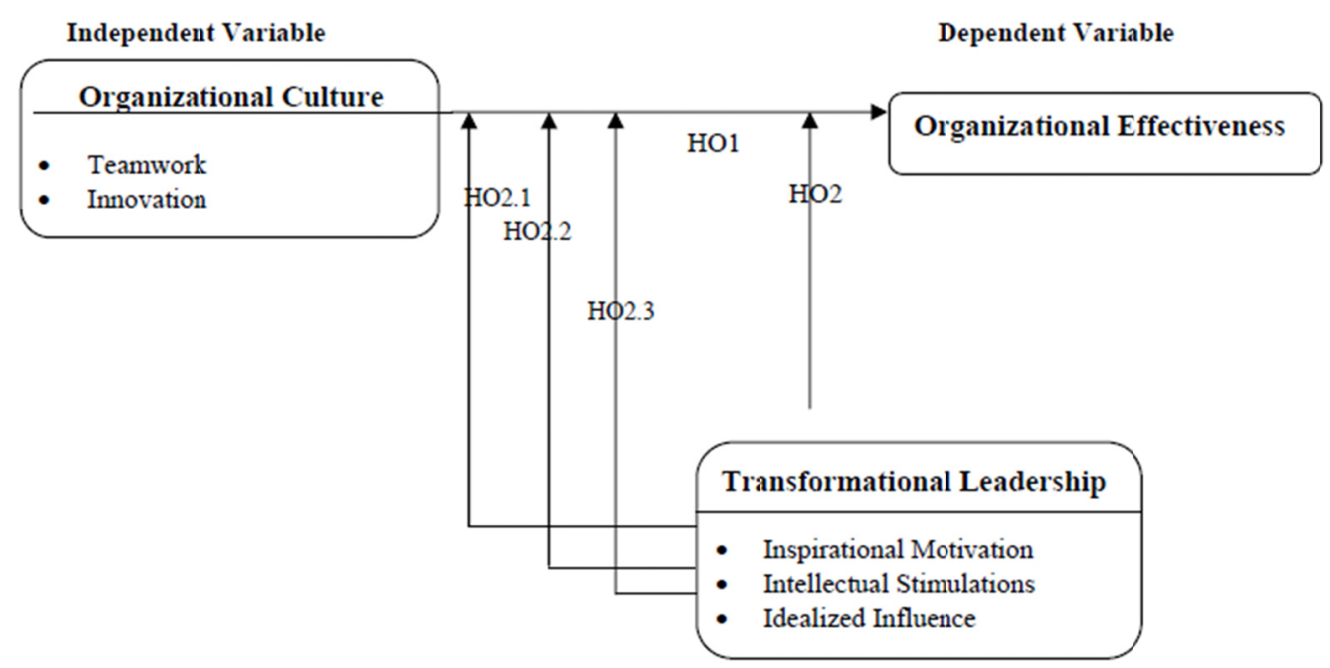

Figure1. Study model

Sources: Model was developed based on the previous studies: Independent variable: (Kanter, 1983; Hsu, 2002; Zheng, 2005), Moderating Variable (Bass and Avolio, 2005), Dependent variable: (Perry et al., 2002; Kathrins, 2007; Vaziri, 2017).

\section{Study Hypotheses Test}

The main study hypotheses are shown below:

H01: There is no significant effect at level $(\alpha \leq 0.05)$ of Organizational Culture (Teamwork \& Innovation) on Organizational Effectiveness in the Food Companies listed at Amman Stock Exchange.

H02: There is no significant moderating effect at level $(\alpha \leq 0.05)$ of Transformational Leadership (Inspirational Motivation, Intellectual Stimulation, and Idealized Influence) on the relationship between Organizational Culture and Organizational Effectiveness in the Food Companies listed at Amman Stock Exchange.

And the derived Subhypotheses are:

H02.1: There is no significant moderating effect at level $(\alpha \leq 0.05)$ of Inspirational Motivation on the relationship between Organizational Culture and Organizational Effectiveness intheFood Companies listed at Amman Stock Exchange.

H02.2: There is no significant moderating effectat level $(\alpha \leq 0.05)$ of Intellectual Stimulation on the relationship between Organizational Culture and Organizational Effectiveness inFood Companies listed at Amman stock exchange.

H02.3: There is no significant moderating effect at level $(\alpha \leq 0.05)$ of Idealized Influence on the relationship between Organizational Culture and Organizational Effectiveness inFood Companies listed at Amman stock exchange.

H01: There is no significant effect at level $(\alpha \leq 0.05)$ of Organizational Culture (Teamwork \& Innovation) on Organizational Effectiveness in the Food Companies listed at Amman Stock Exchange.

To test this hypothesis; a multiple regression analysis was conducted to identify the effect Organizational Culture (Teamwork \& Innovation) on Organizational Effectiveness in these companies. As shown in table below:

Table 1. Multiple regression analysis to ensure the effect of organizational culture on organizational effectiveness

\begin{tabular}{|c|c|c|c|c|c|c|c|c|c|c|}
\hline \multirow{2}{*}{$\begin{array}{c}\text { Dependent } \\
\text { variable }\end{array}$} & \multicolumn{3}{|c|}{ Model Summary } & \multicolumn{3}{|c|}{ ANOVA } & \multicolumn{4}{|c|}{ Coefficients } \\
\hline & (R) & $\left(\mathrm{R}^{2}\right)$ & $\begin{array}{c}\text { Adjusted } \\
\left(\mathrm{R}^{2}\right)\end{array}$ & $\begin{array}{c}\text { F } \\
\text { Calculate }\end{array}$ & DF & Sig* & & $\beta$ & $\begin{array}{c}\mathrm{T} \\
\text { calculate }\end{array}$ & Sig* \\
\hline $\begin{array}{l}\text { Organizational } \\
\text { Effectiveness }\end{array}$ & 0.730 & 0.534 & 0.530 & 133.297 & 2 & 0.000 & $\begin{array}{l}\text { Team } \\
\text { work }\end{array}$ & 0.106 & 1.935 & 0.048 \\
\hline & & & & & 233 & & Innovation & 0.664 & 12.086 & 0.000 \\
\hline
\end{tabular}

* The impact is significant at level $(\alpha \leq 0.05)$ 
Table shows a statistically significant effect of Organizational Culture (Teamwork, Innovation) on Organizational Effectiveness in the Food Companies listed at Amman Stock Exchange. The regression model achieves a good degree of fit, as the values of $(\mathrm{R}=0.730)$ indicates that there is a positive effect of Organizational Culture on Organizational Effectiveness, and the adjusted $\left(R^{2}=0.530\right)$ means that the value of $53 \%$ of the explained variance in Organizational Effectiveness in these Companies can be accounted for Organizational Culture (Teamwork \& Innovation). In addition, the adjusted $\left(R^{2}=0.530\right)$ is very close to the $R^{2}$ value, when excluding the adjusted $\mathrm{R}^{2}$ from $\mathrm{R}^{2}(0.534-0.530=0.004)$, this deficiency means that if the model had been fitted when the whole population participates in the study, the higher variance in the outcome will be 0.004 .

As illustrated in the table, the ANOVA section shows the analysis of variance of the fitted regression equation is significant with $(\mathrm{F}=133.297)$ with $\mathrm{p}$-value less than $(0.05)$ this indicates that Organizational Culture (Teamwork \& Innovation) has a significant impact on Organizational Effectiveness in these companies at $95 \%$ confidence level. On the other hand, in the coefficients section; the $\beta$ values were: for Teamwork $(0.106)$ with p-value (0.048) \& for Innovation (0.664) with p-value (0.000), showing the slope values for the regression line. These values suggested that one unit increase in Organizational Culture (Teamwork dimension) can significantly predict a (0.106) increase in Organizational Effectiveness, and one unit increase in Organizational Culture (Innovation dimension) can significantly predict a (0.664) increase in organizational effectiveness in these Companies.

The results explained from the table above shows the effect of organizational culture on organizational effectiveness in the targeted companies listed; these results reject the first null hypothesis (H01) and accept the alternative hypothesis "There is a significant effect at level $(\alpha \leq 0.05)$ of Organizational Culture (teamwork \& Innovation) on Organizational Effectiveness in the Food Companies listed at Amman Stock Exchange ".

H02: There is no significant moderating effect at level $(\alpha \leq 0.05)$ of Transformational Leadership (Inspirational Motivation, Intellectual Stimulation, and Idealized Influence) on the relationship between Organizational Culture and Organizational Effectiveness in the Food Companies listed at Amman Stock Exchange.

To test this null hypothesis and its sub null hypothesis as shown in the research model, a hierarchical multiple regression analysis was conducted to explore the moderating effect of Transformational Leadership (Inspirational Motivation, Intellectual Stimulation, \& Idealized Influence) on the relationship between Organizational Culture and Organizational Effectiveness in these Companies. Tables below show the results of the hierarchical multiple regression analysis.

Table 2. Hierarchical multiple regression analysis to explore the moderating effect of transformational leadership on the relationship between organizational culture and organizational effectiveness

\begin{tabular}{|c|c|c|c|c|c|c|c|}
\hline \multirow[t]{2}{*}{ Dependent variable } & \multirow[t]{2}{*}{ Independent variable } & \multicolumn{3}{|c|}{ Model 1} & \multicolumn{3}{|c|}{ Model 2} \\
\hline & & $\mathrm{B}$ & T calculate & Sig* & $\beta$ & T calculate & Sig* \\
\hline \multirow{6}{*}{ Organizational Effectiveness } & Organizational Culture & 0.683 & 14.288 & 0.000 & & -- & \\
\hline & Organizational Culture & & & & 0505 & 11367 & 0000 \\
\hline & $\mathbf{X}$ Transformational Leadership & & -- & & 0.595 & $11.50 /$ & 0.000 \\
\hline & $\mathrm{R}$ & & 0.683 & & & 0.703 & \\
\hline & $\mathrm{R}^{2}$ & & 0.466 & & & 0.495 & \\
\hline & $\Delta \mathrm{R}^{2}$ & & 0.466 & & & 0.029 & \\
\hline
\end{tabular}

* The impact is significant at level $(\alpha \leq 0.05)$

$* \mathrm{~F}$ value in model 1 equals (204.150), with sig*0 .000

$* \Delta \mathrm{F}$ value in model 2 equals (114.028), with $\Delta$ sig* 0.000

The first model reflected is based on the values of the correlation coefficient $(\mathrm{R}=0.683)$, which demonstrates that there is a positive effect of Organizational Culture on Organizational Effectiveness. Also, the results show the statistically significant effect of Organizational Culture on Organizational Effectiveness with F value of (204.150) and a P-value less than $(0.05)$. Also, the value of adjusted $\left(\mathrm{R}^{2}=0.466\right)$ indicates that the organizational culture explains $47 \%$ of the variance in Organizational Effectiveness in these Companies.

In the second model, the entry of the moderating variable (Transformational Leadership) to the regression model increased the value of the correlation coefficient to become $(\mathrm{R}=0.703)$, as well as the value of the adjusted $\mathrm{R}^{2}$ increased $2.9 \%$ to become $\left(R^{2}=0.495\right)$ and this percentage is significant, where the $\Delta F$ value $(114.028)$ with a $\Delta$ 
P-value less than (0.05). As the slope value $(\beta=0.595)$ at Transformational Leadership and the (t calculate) value was (11.367) with P-value less than (0.05). This confirms that there is a statistically significant effect of Transformational Leadership (moderating variable) on the relationship between Organizational Culture and Organizational Effectiveness in the targeted Companies. Consequently, the second null hypothesis was rejected and the alternative hypothesis was accepted "There is a significant moderating effect at level $(\alpha \leq 0.05)$ of Transformational Leadership on the relationship between Organizational Culture and Organizational Effectiveness in Food Companies listed at Amman Stock Exchange ".

H02.1: There is no significant moderating effect at level $(\alpha \leq 0.05)$ of Inspirational Motivation on the relationship between Organizational Culture and Organizational Effectiveness in the Food Companies listed at Amman Stock Exchange.

Table 3. Hierarchical multiple regression analysis to explore the effect of Inspirational Motivation on the relationship between Organizational Culture and Organizational Effectiveness

\begin{tabular}{|c|c|c|c|c|c|c|c|}
\hline \multirow[t]{2}{*}{ Dependent variable } & \multirow[t]{2}{*}{ Independent variable } & \multicolumn{3}{|c|}{ Model 1} & \multicolumn{3}{|c|}{ Model 2} \\
\hline & & $\beta$ & T calculate & Sig* & $\beta$ & T calculate & Sig* \\
\hline & Organizational Culture & 0.683 & 14.288 & 0.000 & & -- & \\
\hline & Organizational Culture & & & & & & \\
\hline \multirow[t]{5}{*}{ Organizational Effectiveness } & $\mathbf{X}$ & & -- & & 0.636 & 12.524 & 0.000 \\
\hline & Inspirational Motivation & & & & & & \\
\hline & $\mathrm{R}$ & & 0.683 & & & 0.693 & \\
\hline & $\mathrm{R}^{2}$ & & 0.466 & & & 0.480 & \\
\hline & $\Delta \mathrm{R}^{2}$ & & 0.466 & & & 0.014 & \\
\hline
\end{tabular}

* The impact is significant at level $(\alpha \leq 0.05)$

$*$ F value in model 1 equals (204.150), with sig*0 .000

$* \Delta \mathrm{F}$ value in model 2 equals (114.028), with $\Delta$ sig* 0.000

The first model reflected is based on the values of the correlation coefficient $(R=0.683)$ which demonstrates that there is a positive effect of Organizational Culture on Organizational Effectiveness. Also the results show the statistically significant effect of Organizational Culture on Organizational Effectiveness with $\mathrm{F}$ value of (204.150) and a P-value less than (0.05). Also, the value of adjusted $\left(\mathrm{R}^{2}=0.466\right)$ indicates that the Organizational Culture explains $47 \%$ of the variance in Organizational Effectiveness in these Companies.

In the second model, the entry of the moderating variable dimension (Inspirational Motivation) to the regression model increased the value of the correlation coefficient to become $(\mathrm{R}=0.693)$ as well as the value of the adjusted $\mathrm{R}^{2}$ increased $1.4 \%$ to become $\left(\mathrm{R}^{2}=0.480\right)$ and this percentage is significant, where the $\Delta \mathrm{F}$ value $(107.408)$ with a $\Delta \mathrm{P}$-value less than $(0.05)$. As the slope value $(\beta=0.636)$ at Inspirational Motivation and the $(\mathrm{t}$ calculate) value was (12.524) with $\mathrm{P}$-value less than $(0.05)$. This confirms that there is a statistically significant effect of Inspirational Motivation on the relationship between Organizational Culture and Organizational Effectiveness in the targeted Companies. Consequently, the first sub hypothesis of the second null hypothesis was rejected and the alternative hypothesis was accepted "There is a significant moderating effect at level ( $\alpha \leq$ 0.05) of Inspirational Motivation on the relationship between Organizational Culture and Organizational Effectiveness in Food Companies listed at Amman stock exchange".

H02.2: There is no significant moderating effectat level $(\alpha \leq 0.05)$ of Intellectual Stimulation on the relationship between Organizational Culture and Organizational Effectiveness inFood Companies listed at Amman stock exchange. 
Table 4. Hierarchical multiple regression analysis to explore the effect of intellectual stimulation on the relationship between organizational culture and organizational effectiveness

\begin{tabular}{|c|c|c|c|c|c|c|c|}
\hline \multirow[t]{2}{*}{ Dependent variable } & \multirow[t]{2}{*}{ Independent variable } & \multicolumn{3}{|c|}{ Model 1} & \multicolumn{3}{|c|}{ Model 2} \\
\hline & & $\beta$ & T calculate & Sig* & $\beta$ & T calculate & Sig* \\
\hline & Organizational Culture & 0.683 & 14.288 & 0.000 & & -- & \\
\hline & Organizational Culture & & & & & & \\
\hline \multirow[t]{5}{*}{ Organizational Effectiveness } & $\mathbf{X}$ & & -- & & 0.602 & 11.746 & 0.000 \\
\hline & Intellectual Stimulation & & & & & & \\
\hline & $\mathrm{R}$ & & 0.683 & & & 0.705 & \\
\hline & $\mathrm{R}^{2}$ & & 0.466 & & & 0.496 & \\
\hline & $\Delta \mathrm{R}^{2}$ & & 0.466 & & & 0.030 & \\
\hline
\end{tabular}

* The impact is significant at level $(\alpha \leq 0.05)$

$* F$ value in model 1 equals (204.150), with sig*0 000

$* \Delta \mathrm{F}$ value in model 2 equals (114.028), with $\Delta$ sig* 0.000

The first model reflected is based on the values of the correlation coefficient $(\mathrm{R}=0.683)$, which demonstrates that there is a positive effect of Organizational Culture on Organizational Effectiveness. Also the results show the statistically significant effect of Organizational Culture on Organizational Effectiveness with $\mathrm{F}$ value of (204.150) and a P-value less than (0.05). Also, the value of the adjusted $\left(\mathrm{R}^{2}=0.466\right)$ indicates that the Organizational Culture explains $47 \%$ of the variance in Organizational Effectiveness in these Companies.

In the second model, the entry of the moderating variable dimension (Intellectual Stimulation) to the regression model increased the value of the correlation coefficient to become $(\mathrm{R}=0.705)$ as well as the value of the adjusted $\mathrm{R}^{2}$ increased $3 \%$ to become $\left(\mathrm{R}^{2}=0.496\right)$ and this percentage is significant, where the $\Delta \mathrm{F}$ value (114.817) with a $\Delta \mathrm{P}$-value less than (0.05). As the slope value $(\beta=0.602)$ at Intellectual Stimulation and the $(\mathrm{t}$ calculate) value was (11.746) with P-value less than (0.05). This confirms that there is a statistically significant effect of intellectual stimulation on the relationship between Organizational Culture and Organizational Effectiveness in the targeted companies. Consequently, the second sub hypothesis of the second null hypothesis was rejected and the alternative hypothesis was accepted "There is a significant moderating effect at level $(\alpha \leq$ 0.05) of Intellectual Stimulation on the relationship between Organizational Culture and Organizational Effectiveness in Food Companies listed at Amman stock exchange".

H02.3: There is no significant moderating effect at level $(\alpha \leq 0.05)$ of Idealized Influence on the relationship between Organizational Culture and Organizational Effectiveness inFood Companies listed at Amman stock exchange.

Table 5. Hierarchical multiple regression analysis to explore the effect of idealized influence on the relationship between organizational culture and organizational effectiveness

\begin{tabular}{cccccccc}
\hline Dependent variable & Independent variable & Model 1 & & Model 2 & \\
& & $\beta$ & T calculate & Sig* & $\beta$ & T calculate & Sig* \\
\hline & Organizational Culture & 0.683 & 14.288 & .000 & & -- & \\
& Organizational Culture & & & & & & \\
Organizational Effectiveness & $\mathbf{X}$ & -- & & 0.604 & 11.596 & .000 \\
& Idealized Influence & & & & & \\
& $\mathrm{R}$ & 0.683 & & & 0.701 & \\
$\mathrm{R}^{2}$ & & 0.466 & & & 0.492 \\
& $\Delta \mathrm{R}^{2}$ & & 0.466 & & & 0.026 \\
\hline
\end{tabular}

* The impact is significant at level $(\alpha \leq 0.05)$.

$*$ F value in model 1 equals (204.150), with sig*0 .000 .

$* \Delta \mathrm{F}$ value in model 2 equals (114.028), with $\Delta$ sig* 0.000 .

The first model reflected is based on the values of the correlation coefficient $(\mathrm{R}=0.683)$ which demonstrates that there is a positive effect of Organizational Culture on Organizational Effectiveness. Also the results show the statistically significant effect of Organizational Culture on Organizational Effectiveness with $\mathrm{F}$ value of (204.150) and a P-value less than (0.05). Also, the value of the adjusted $\left(\mathrm{R}^{2}=0.466\right)$ indicates that the 
Organizational Culture explains $47 \%$ of the variance in Organizational Effectiveness in these Companies.

In the second model, the entry of the moderating variable dimension (Idealized Influence) to the regression model increased the value of the correlation coefficient to become $(\mathrm{R}=0.701)$ as well as the value of the adjusted $\mathrm{R}^{2}$ increased $2.6 \%$ to become $\left(\mathrm{R}^{2}=0.492\right)$ and this percentage is significant, where the $\Delta \mathrm{F}$ value (112.358) with a $\Delta$ P-value less than $(0.05)$. As the slope value $(\beta=0.604)$ at Idealized Influence and the $(\mathrm{t}$ calculate) value was (11.596) with P-value less than (0.05). This confirms that there is a statistically significant effect of Idealized Influence on the relationship between Organizational Culture and Organizational Effectiveness in the targeted companies. Consequently, the third sub hypothesis of the second null hypothesis was rejected and the alternative hypothesis was accepted "There is a significant moderating effect at level $(\alpha \leq$ $0.05)$ of Idealized Influence on the relationship between Organizational Culture and Organizational Effectiveness in the Food Companies listed at Amman Stock Exchange".

\section{Results and Discussion}

The results of the study assured that there is a significant statistical effect of Organizational Culture on Organizational Effectiveness in Food Companies listed at Amman Stock Exchange at $(\alpha \leq 0.05)$. These results agree with: Flemming 2017study's result that there was sufficient evidence that effectiveness depends on organizational culture types; Hartnell \& Kinicki 2011 study's result which revealed that the culture types are significantly associated with organizational effectiveness. Also the results shows that there is a significant statistical moderating effect of transformational leadership on the relationship between organizational culture (teamwork \& innovation) and organizational effectiveness in Food Companies listed at Amman Stock Exchange at $(\alpha \leq 0.05)$.These results agree with: Mamo 2017 study's result which indicated that the influence of organizational leadership on organizational effectiveness is partially mediated by organizational culture; Vaziri 2017 study's result which showed that the managers directly and indirectly have positive and significant effect with the mediating role of organizational culture on organizational effectiveness. In addition, There is a significant statistical moderating effect of Inspirational Motivation on the relationship between Organizational Culture (Teamwork \& Innovation) and Organizational Effectiveness in Food Companies listed at Amman Stock Exchange at $(\alpha \leq 0.05)$; and these resultsagree with Abuhlaleh 2016study's result indicated that inspirational motivation increase level of organizational effectiveness.

Results shows that there is a significant statistical moderating effect of Intellectual Stimulation on the relationship between Organizational Culture (Teamwork \& Innovation) and Organizational Effectiveness in Food Companies listed at Amman Stock Exchange at $(\alpha \leq 0.05)$.These resultsagree with Abuhlaleh 2016study's result indicated that intellectual stimulation had a positive direction of the correlation with organizational effectiveness. And there is a significant statistical moderating effect of Idealized Influence on the relationship between Organizational Culture (Teamwork \& Innovation) and Organizational Effectiveness in Food Companies listed at Amman Stock Exchange at $(\alpha \leq 0.05)$, which agree with Abuhlaleh 2016study's result that significant relationship exists between idealized influence and organizational effectiveness;Berglund 2014research result that showed that transformational leadership dimension (Idealized Influence) emerged as the most important factor effect the organizational culture dimensions.

\section{Conclusions}

After discussing the study results, this study concluded that: The level of Teamwork in the surveyed companies was high; This indicates that companies' individuals prefer working in harmony, helping each other's, and cooperation. And the level of Innovation in the surveyed companies was medium; This indicates that these companies consider the innovation to be of medium importance but not a fundamental consideration within corporate culture. This might be due to the fact that the nature of food industry does not demand and classify Innovation as a top priority. Also; the level of Transformational Leadership (Inspirational Motivation, Intellectual Stimulation, and Idealized Influence) in the surveyed companies was high. This indicates that within these companies there is a good number of Transformational Leaders who support and encourage individuals, motivate them, pay attention to their opinions about products or procedures, display a sense of power and confidence and act in a way that make others respect him as a leader. In Addition; the level of organizational effectiveness in the surveyed companies was average; this may be due to the multiplicity and diversity of dimensions and indicators used in this study to measure organizational effectiveness, which makes it difficult for these companies to achieve superior performance for all these dimensions.

\section{Recommendations}

Based on the study results; the targeted Companies are recommended to: Facilitate, encourage and provide the requirements for teamwork and innovation as dimensions of organizational culture, which has a positive impact 
on organizational effectiveness through training programs. And; to encourage their managers to support teamwork in performing tasks and solving work problems by spreading a culture of positive dialogue in exchange of ideas and opinions within their culture. Also; to develop a mechanism to select working teams members in terms of experience, skills and good relationships and provide information, data and resources to those teams and give them the powers necessary to work effectively. And to identify and detect the factors that affect innovation negatively and positively by regular assessment, monitoring and directly asking individuals about this matter to benefit from it as a feedback and to make it as a culture of the company and not just as a policy to deal with problems only. Adding to that; they need to build a culture that allows improving the abilities of the employees, releasing their energies, making positive changes in the working methods and facing organizational problems by tolerating with mistakes and errors at work to enhance their innovative behavior and achieve higher levels of innovation. And to be aware about the importance of providing the appropriate climate for the emergence of creative ideas and creating the conditions for innovation. In addition; these companies need to consider hiring individuals who have transformational leadership characteristics through hiring processes (advertisement, screening, interviewing etc.) -having the right person in the right place- to keep high levels of transformational leadership due to their positive effect on company's culture and effectiveness. At last; these companies need to adopt behavioral training programs for the current leadership to promote the transformational leadership style and create a climate of mutual trust and respect with employees and inspire and motivate them intellectually to increase the positive impact of transformational leadership on the relationship between organizational culture and organizational effectiveness.

\section{References}

Abuhlaleh, A. (2016). The Impact of Interscholastic Athletic Directors' Transformational Leadership Style and Gender on Organizational Effectiveness (Doctoral dissertation, Concordia University Chicago).

Aghayi, M., Aghayi, A., \& Aghayi, R. (2011). The evaluation of the effect of culture strategy, structure, organizational effectiveness and knowledge management. The studies of improvement and change management, 105-125.

Antonakis, J., \& House, R. J. (2014). Instrumental leadership: Measurement and extension of transformationaltransactional leadership theory. The Leadership Quarterly, 25(4), 746-771. https://doi.org/10.1016/j.leaqua.2014.04.005

Arundel, A., Casali, L., \& Hollanders, H. (2015). How European public sector agencies innovate: The use of bottom-up, policy-dependent and knowledge-scanning innovation methods. Research Policy, 44(7), 1271-1282. https://doi.org/10.1016/j.respol.2015.04.007

Balduck, A. L., \& Buelens, M. (2008). A two-level competing values approach to measure nonprofit organizational effectiveness. Ghent University: Vlerick Leuven Gent Management School.

Banerji, P., \& Krishnan, V. R. (2000). Ethical preferences of transformational leaders: An empirical investigation. Leadership \& Organization Development Journal, 21(8), 405-413. https://doi.org/10.1108/01437730010358161

Bass, B. M. (1990). From transactional to transformational leadership: Learning to share the vision. Organizational dynamics, 18(3), 19-31. https://doi.org/10.1016/0090-2616(90)90061-S

Bass, B. M. (1997). Does the transactional-transformational leadership paradigm transcend organizational and national boundaries? American psychologist, 52(2), 130. https://doi.org/10.1037/0003-066X.52.2.130

Bass, B. M., \& Avolio B. J, (2005). Improving organizational effectiveness through transformational leadership. Thousand Oak: Sage Publication.

Bass, B. M., \& Avolio, B. J. (1994). Improving organizational effectiveness through transformational leadership.

Bass, B. M., \& Riggio, R. E. (2006). Transformational Leadership. Lawrence Erlbaum Associates. Mahwah, NJ.

Bennis, W. (2001). Farewell to Old Leadership, in Management and Leadership in the Information Age. Abu Dhabi: Emirates Centre for Strategic Studies and Research, 29-58.

Berglund, M. (2014). A study to explore the relationship between leadership and organizational culture in a government organization. Grand Canyon University

Burns, J. M. (1978). Leadership. NY: Harper \& Row.

Chelladurai, P., \& Haggerty, T. (1991). Measures of organizational effectiveness of Canadian national sport organizations. Canadian journal of sport sciences = Journal canadien des sciences du sport, 16(2), 126-133. 
Cheng, Y. N., Yen, C. L., \& Chen, L. H. (2012). Transformational leadership and job involvement: The moderation of emotional contagion. Military Psychology, 24(4), 382. https://doi.org/10.1080/08995605.2012.695261

Chesbrough, H. W. (2006). Open innovation: The new imperative for creating and profiting from technology. Harvard Business Press.

Cho, C., Halford, J. T., Hsu, S., \& Ng, L. (2016). Do managers matter for corporate innovation? Journal of Corporate Finance, 36, 206-229. https://doi.org/10.1016/j.jcorpfin.2015.12.004

Converse, S., Cannon-Bowers, J. A., \& Salas, E. (1993). Shared mental models in expert team decision making. Individual and group decision making: Current issues, 221.

Deal, T. E., \& Kennedy, A. A. (2000). The new corporate cultures: Revitalizing the workplace after downsizing, mergers, and reengineering. Basic Books.

Eisenbach, R., Watson, K., \& Pillai, R. (1999). Transformational leadership in the context of organizational change. Journal of Organizational Change Management, 12(2), 80-89. https://doi.org/10.1108/09534819910263631

Flemming, P. L. (2017). Building a Climate of Change with a link through Transformational Leadership and Corporate Culture: A Management key to a Global Environment. International Journal of Business and Social Research, 7(1), 44-55. https://doi.org/10.18533/ijbsr.v7i01.1033

Gilmore, P. L., Hu, X., Wei, F., Tetrick, L. E., \& Zaccaro, S. J. (2013). Positive affectivity neutralizes transformational leadership's influence on creative performance and organizational citizenship behaviors. Journal of Organizational Behavior, 34(8), 1061-1075. https://doi.org/10.1002/job.1833

Griffith, J. (2004). Relation of principal transformational leadership to school staff job satisfaction, staff turnover, and school performance. Journal of Educational Administration, 42(3), 333-356. https://doi.org/10.1108/09578230410534667

Hammond, M. M., Neff, N. L., Farr, J. L., Schwall, A. R., \& Zhao, X. (2011). Predictors of individual-level innovation at work: A meta-analysis. Psychology of Aesthetics, Creativity, and the Arts, 5(1), 90. https://doi.org/10.1037/a0018556

Hartmann, A. (2006). The role of organizational culture in motivating innovative behaviour in construction firms. Construction innovation, 6(3), 159-172. https://doi.org/10.1108/14714170610710712

Hartnell, C. A., Ou, A. Y., \& Kinicki, A. (2011). Organizational culture and organizational effectiveness: a meta-analytic investigation of the competing values framework's theoretical suppositions. Journal of Applied Psychology, 96(4), 677. https://doi.org/10.1037/a0023086https://doi.org/10.1037/a0021987

Hater, J. J., \& Bass, B. M. (1988). Superiors' evaluations and subordinates' perceptions of transformational and transactional leadership. Journal of Applied Psychology, 73(4), 695. https://doi.org/10.1037/0021-9010.73.4.695

Hernez-Broome, G., \& Hughes, R. L. (2004). Leadership development: Past, present, and future. People and Strategy, 27(1), 24.

Heskett, J. L., \& Kotter, J. P. (1992). Corporate culture and performance. Business Review, 2, 83-93

Hofstede, G., Hofstede, G.J., Minkov, M., 2010. Cultures and Organizations: Software of the Mind (3rd ed.). McGraw-Hill Education. https://doi.org/10.1108/13527601111104269

Hsu, C. (2002). A structural equation modeling analysis of transformational leadership, organizational culture and organizational effectiveness in taiwanese sport /fitness organizations. ProQuest Dissertations \& Theses Global.

Jehangir, M., Kareem, N., Khan, A., \& Jan. M. T. (2011). Effects of job stress on job performance and job satisfaction. Interdisciplinary Journal of Contemporary Research in Business, 3(7), 453-465. Retrieved from $\mathrm{http}: / /$ irep.iium.edu.my/id/eprint/26715

Jones, G. R. (2013). Organizational theory, design, and change. Pearson.

Jung, T., Scott, T., Davies, H. T., Bower, P., Whalley, D., McNally, R., \& Mannion, R. (2009). Instruments for exploring organizational culture: A review of the literature. Public Administration Review, 69(6), 1087-1096. https://doi.org/10.1111/j.1540-6210.2009.02066.x

Kanter, R.M. (1983). The changing masters: Innovation for productivity in the American Corporation. New York: 
Simon and Schuster.

Kathrins, R. (2007). The relationship of leadership style and types of organizational culture to the effectivness and employee satisfaction in acute care hospital (Vol. 68, No. 2)

Kent, R. A. W. (1995). Organizational effectiveness, executive leadership and organization culture: A study of selected provincial sport organizations

Kessler, E. H., \& Chakrabarti, A. K. (1996). Innovation speed: A conceptual model of context, antecedents, and outcomes. Academy of Management Review, 21(4), 1143-1191. https://doi.org/10.5465/amr.1996.9704071866

Kilmann, R. H., Saxton, M. J., \& Serpa, R. (1985). Gaining control of the corporate culture. Jossey-Bass Inc Pub.

Kroeber, A. L., \& Kluckhohn, C. (1952). Culture: A critical review of concepts and definitions. Peabody Museum of Archaeology \& Ethnology, Harvard University.

Liu, Y. (2013). Sustainable competitive advantage in turbulent business environments. International Journal of Production Research, 51(10), 2821-2841. https://doi.org/10.1080/00207543.2012.720392

Liu, Y., \& Liang, L. (2015). Evaluating and developing resource-based operations strategy for competitive advantage: an exploratory study of Finnish high-tech manufacturing industries. International Journal of Production Research, 53(4), 1019-1037. https://doi.org/10.1080/00207543.2014.932936

Long, C. S., Thean, L. Y., \& Kowang, O. T. (2013). The transformational leadership: A possible TQM solution to increase job satisfaction. Life Science Journal, 10(4), 1474-1484.

Mamo, D. (2017). The Link between Organizational Leadership, Organizational Effectiveness and the Mediating Effect of Organizational Culture in HEIs in Ethiopia.

Marcoulides, G. A., \& Heck, R. H. (1993). Organizational culture and performance: Proposing and testing a model. Organization science, 4(2), 209-225. https://doi.org/10.1287/orsc.4.2.209

Nanjundeswaraswamy, T., \& Swamy, D. (2014). Leadership Styles. Advances in Management, 7(2), 57.

Newman, G. (2012). The effect of leadership styles on leader effectiveness, employee satisfaction, and employee effort in a local government (Doctoral dissertation, Walden University) Northouse, P. G. (2010). Leadership: Theory and practice: Sage publications.

Ogbonna, E., \& Harris, L. (2000). Leadership style, organizational culture and performance: Empirical evidence from UK companies. International Journal of Human Resources Management, 11(4), 766-788. https://doi.org/10.1080/09585190050075114

Parry, K. W., \& Proctor-Thomson, S. B. (2002). Perceived integrity of transformational leaders in organisational settings. Journal of Business Ethics, 35(2), 75-96. https://doi.org/10.1023/A:1013077109223

Pettigrew, A. M. (1979). On studying organizational cultures. Administrative science quarterly, 24(4), $570-581$. https://doi.org/10.2307/2392363

Robbins, S. P., \& Judge, T. A. (2013). Organizational behavior (15th ed.). Boston: Pearson.

Salas, E., Montero, R. C., Glickman, A. S., \& Morgan, B. B. (1988). Group development, teamwork skills, and training. American Psychological.

Sanfilippo, F., Bendapudi, N., Rucci, A., \& Schlesinger, L. (2008). Strong leadership and teamwork drive culture and performance change: Ohio State University Medical Center 2000-2006. Academic Medicine, 83(9), 845-854. https://doi.org/10.1097/ACM.0b013e318181d2e7

Sashkin, M., \& Sashkin, M. G. (1990). Leadership and Culture-Building in Schools: Quantitative and Qualitative Understandings.

Saxe, D. (2011). The relationship between transformational leadership and the emotional and social competence of the school leader (Doctoral dissertation, Loyola University Chicago).

Schein, E. H. (1990). Organizational culture (Vol. 45): American Psychological Association.

Schein, E. H. (2010). Organizational culture and leadership (Vol. 2): John Wiley \& Sons.

Shivers-Blackwell, S. (2006). The Influence of Perceptions of Organizational Structure \& Culture on Leadership Role Requirements: The Moderating Impact of Locus of Control \& Self-Monitoring. Journal of Leadership \& Organizational Studies, 12(4), 27-49. https://doi.org/10.1177/107179190601200403 
Thompson, L. (2003). Improving the creativity of organizational work groups. Academy of Management Perspectives, 17(1), 96-109. https://doi.org/10.5465/ame.2003.9474814

Tichy, N. M., \& Devanna, M. A. (1986). The transformational leader. New York: Wiley.

Tidd, J. (2001). Innovation management in context: environment, organization and performance. International Journal of Management Reviews, 3(3), 169-183. https://doi.org/10.1111/1468-2370.00062

Tylor, E. B. (1871). Primitive culture: Researches into the development of mythology, philosophy, religion, art, and custom (Vol. 2): J. Murray.

Vaziri, M. B. (2017). The impact of knowledge management on organizational effectiveness with the mediating role of organizational culture. QUID: Investigación, Ciencia y Tecnología, (1), 37-48.

Vinitwatanakhun, W. (2015). Factors affecting organizational effectiveness of nursing institutes in Thailand.

Zheng, W. (2005). The impact of organizational culture, structure, and strategy on knowledge management effectiveness and organizational effectiveness. University of Minnesota.

\section{Copyrights}

Copyright for this article is retained by the author(s), with first publication rights granted to the journal.

This is an open-access article distributed under the terms and conditions of the Creative Commons Attribution license (http://creativecommons.org/licenses/by/4.0/). 